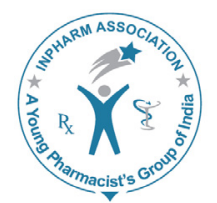

\title{
Development and Validation of Stability Indicating RP-HPLC Method for Simultaneous Estimation of Paracetamol and Flupirtine maleate in Pure and Pharmaceutical Dosage Forms
}

\author{
Mallikarjunarao Nagasarapu1, Gowrisankar Dananna² \\ ${ }^{1}$ Department of Pharmaceutical Sciences, Jawaharlal Nehru Technological University, Kakinada, Andhra \\ Pradesh, India. \\ ${ }^{2}$ Department of Pharmaceutical Analysis \& Quality Assurance, University College of Pharmaceutical \\ Sciences, Andhra University, Visakhapatnam, Andhra Pradesh, India.
}

\begin{abstract}
Objective: The objective of the proposed method was to develop a simple, fast, sensitive, and validated high-performance liquid chromatography (HPLC) method for the simultaneous estimation of Paracetamol and Flupirtine Maleate in combineddosage form. Materials and Methods: A Hypersil BDS C18, $150 \times 4.6,5 \mu$ column with mobile phase containing Phosphate buffer (Ph 6.2): Acetonitrile (600:400) was used. The flow rate was $1.0 \mathrm{~mL} / \mathrm{min}$, column temperature was $30^{\circ} \mathrm{C}$ and effluents were monitored at $245 \mathrm{~nm}$. The retention times of Paracetamol and Flupirtine Maleate were $3.1 \mathrm{~min}$ and 5.2 min respectively. Results: The correlation co-efficient for Paracetamol and Flupirtine Maleate were found to be 0.99 and 1 respectively. The proposed method was validated with respect to linearity, accuracy, precision, specificity, and robustness. Recovery of Paracetamol and Flupirtine Maleate in formulations was found to be $100 \%$ and $100 \%$ respectively confirms the noninterferences of the excipients in the formulation. Degradation studies reveals that purity threshold is greater than the purity angle hence the peak is said to be pure. Conclusion: Due to its simplicity, rapidness and high precision, this method was successfully applied to the estimation of Paracetamol and Flupirtine Maleate in combined dosage form.
\end{abstract}

Key words: Flupritine maleate, method development, paracetamol, RP-HPLC, stability indicating and validation.

\begin{tabular}{|c|c|}
\hline \multicolumn{2}{|c|}{ Access this article online } \\
\hline Journal Sponsor & \multirow[b]{2}{*}{$\begin{array}{l}\text { Website: } \\
\text { www.jyoungpharm.org }\end{array}$} \\
\hline \multirow{2}{*}{ www.phcog net } & \\
\hline & DOI: 10.5530/jyp.2015.2.5 \\
\hline
\end{tabular}

\section{INTRODUCTION}

Paracetamol is chemically known as N-(4-hydroxyphenyl) acetamide. The empirical formula is $\mathrm{C}_{8} \mathrm{H}_{9} \mathrm{NO}_{2}$. Paracetamol is thought to act primarily in the CNS, increasing the pain threshold by inhibiting both isoforms of cyclo oxygenase, COX-1, COX-2, and COX-3 enzymes involved in prostaglandin (PG) synthesis. It functions as a weak inhibitor of the synthesis of prostaglandins (PGs). ${ }^{1}$ The in vivo

\footnotetext{
*Address for correspondence:

Dr. Mallikarjunarao, Research scholar, Department of Pharmaceutical Sciences, Jawaharlal Nehru Technological University, Kakinada, Andhra Pradesh, India. Email: mallimpharmmba@gmail.com
} 


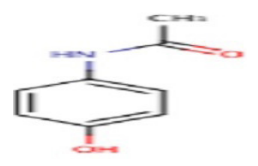

Figure 1: Chemical structure of Paracetamol

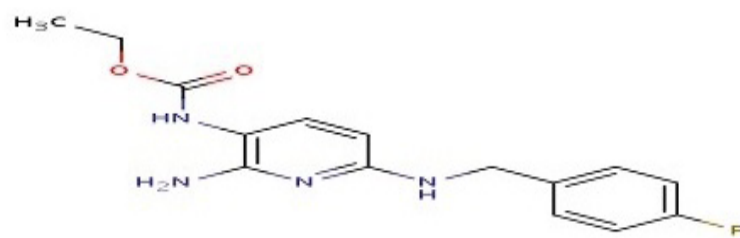

Figure 2: Chemical structure of Flupritine maleate effects of paracetamol are similar to those of the selective cyclooxygenase-2 (COX-2) inhibitors. ${ }^{2}$ Unlike NSAIDs, acetaminophen does not inhibit cyclooxygenase in peripheral tissues and, thus, has no peripheral anti-inflammatory affects. The antipyretic properties of acetaminophen are likely due to direct effects on the heat-regulating centers of the hypothalamus resulting in peripheral validation, sweating and hence heat dissipation. The chemical structure of Paracetamol was shown in Figure 1.

Flupirtineis an aminopyridine that functions as a centrally acting non-opioid analgesic. It is chemically ethyl N-(2amino-6-\{[(4-fluorophenyl) methyl $]$ amino $\}$ pyridin-3-yl) carbamateacts as selective neuronal potassium channel opener that also has NMDA receptor antagonist properties. ${ }^{3}$ The empirical formula is $\mathrm{C}_{15} \mathrm{H}_{17} \mathrm{FN}_{4} \mathrm{O}_{2}$. Flupirtine up regulates $\mathrm{Bcl}-2$, increases glutathione levels, activates an inwardly rectifying potassium channel, and delays loss of intermito chondrial membrane calcium retention capacity. Flupirtine acts like a NMDA receptor antagonists, but does not bind to the receptor. One study concluded that the discriminative effects of flupirtine are neither of opioid nor of alpha- 1 adrenergic type, but are primarily mediated through alpha-2 adrenergic mechanisms. The chemical structure of Flupirtine Maleate was shown in Figure 2.

Literature survey revealed that few analytical methods such as and LC-MS, ${ }^{4} \mathrm{UV}$ spectrophotometric, ${ }^{5-8}$ and HPLC, ${ }^{9-14}$ methods have been reported for the estimation of Flupirtine and hence we tried to develop and validate a new stability indicating RP-HPLC methodas per ICH guidelines ${ }^{15,16}$ for the estimation of Flupirtine maleate and paracetamol in bulk and pharmaceutical dosage forms.

\section{MATERIALS AND METHOD}

\section{Instrumentation}

The separation was carried out on HPLC system with
Waters 2695 alliance with binary HPLC pump, UV-Visible detector, Waters Empower 2 software and column Hypersil BDS C18, $150 \times 4.6,5 \mu$.

\section{Chemicals and reagents}

The working standards of Paracetamol, Flupirtine Maleate were provided as gift samples from Lara drugs Pvt. Ltd., Hyderabad. Marketed formulation of combination was purchased from local market. Methanol of HPLC grade was purchased from E. Merck (India) Ltd., Mumbai. Orthophosphoric Acid and Acetonitrile of AR grade were obtained from S.D. Fine Chemicals Ltd., Mumbai and milli Q water.

\section{HPLC conditions}

The mobile phase consisting of phosphate buffer $\left(\mathrm{p}^{\mathrm{H}} 6.5\right.$ \pm 0.1 adjusted with dilute orthophosphoric acid or dilute potassium hydroxide solution) Acetonitrile (HPLC grade) were filtered through $0.45 \mu \mathrm{m}$ membrane filter before use, degassed and were pumped from the solvent reservoir in the ratio of $600: 400 \mathrm{v} / \mathrm{v}$ was pumped into the column at a flow rate of $1.0 \mathrm{~mL} / \mathrm{min}$. The column temperature was $30^{\circ} \mathrm{C}$. The detection was monitored at $245 \mathrm{~nm}$ and the run time was $10 \mathrm{~min}$. The volume of injection loop was $20 \mu \mathrm{L}$ prior to injection of the drug solution the column was equilibrated for at least $30 \mathrm{~min}$. with the mobile phase flowing through the system.

\section{Preparation of standard solution}

\section{Paracetamol}

Accurately weighed quantity $32.5 \mathrm{mg}$ of Paracetamol was transferred into $100 \mathrm{~mL}$ of volumetric flask, add $30 \mathrm{ml}$ diluent and sonicated to dissolve and diluted to volume with diluent. (Stock solution). From the above solution 10 $\mathrm{ml}$ was taken into $100 \mathrm{ml}$ volumetric flask and diluted to volume with diluent. 
Nagasarapu, et al.: Development and validation of RP-HPLC method for simultaneous estimation of paracetamol and flupirtine maleate

\begin{tabular}{|c|c|c|c|c|}
\hline Actual method & Sample name & RT & Tailing & Plate count \\
\hline Flow (1ml) & Metformin & 3.048 & 1.147 & 6782 \\
\hline $\operatorname{Temp}\left(30^{\circ} \mathrm{C}\right)$ & & & & \\
\hline $\mathrm{PH}(4.5)$ & Linagliptin & 4.457 & 1.096 & 8231 \\
\hline $\begin{array}{l}\text { Mobile phase }(600: 400 \\
\% \text { V/V) }\end{array}$ & & & & \\
\hline
\end{tabular}

\begin{tabular}{|c|c|c|c|c|}
\hline Spiked Level & $\begin{array}{l}\text { Sample Weight } \\
\mathrm{mg} / \mathrm{L}\end{array}$ & Sample Area & $\begin{array}{l}\text { Amount } \\
\text { Recovery }\end{array}$ & $\%$ recovery \\
\hline $50 \%$ & 16.25 & 423769 & 50.15 & 50.15 \\
\hline $50 \%$ & & 424436 & & \\
\hline $50 \%$ & & 424554 & & \\
\hline $100 \%$ & 32.5 & 845094 & 100.02 & 100.02 \\
\hline $100 \%$ & & 845902 & & \\
\hline $100 \%$ & & 846132 & & \\
\hline $150 \%$ & 48.75 & 1271094 & 150.07 & 150.07 \\
\hline $150 \%$ & & 1271435 & & \\
\hline $150 \%$ & & 1265789 & & \\
\hline
\end{tabular}

Table 3: Recovery studies for Flupritine maleate

\begin{tabular}{|c|c|c|c|c|}
\hline Spiked Level & $\begin{array}{c}\text { Sample Weight } \\
\mathrm{mg} / \mathrm{L}\end{array}$ & Sample Area & Amount Recovery & $\%$ recovery \\
\hline $50 \%$ & 5 & 140998 & 50.05 & 100.11 \\
\hline $50 \%$ & & 141323 & & \\
\hline $50 \%$ & & 142096 & & \\
\hline $100 \%$ & 10 & 281325 & 100.28 & 100.28 \\
\hline $100 \%$ & & 283029 & & \\
\hline $100 \%$ & & 283435 & & \\
\hline $150 \%$ & 15 & 422675 & 149.39 & 99.59 \\
\hline $150 \%$ & & 422132 & & \\
\hline $150 \%$ & & 421854 & & \\
\hline
\end{tabular}

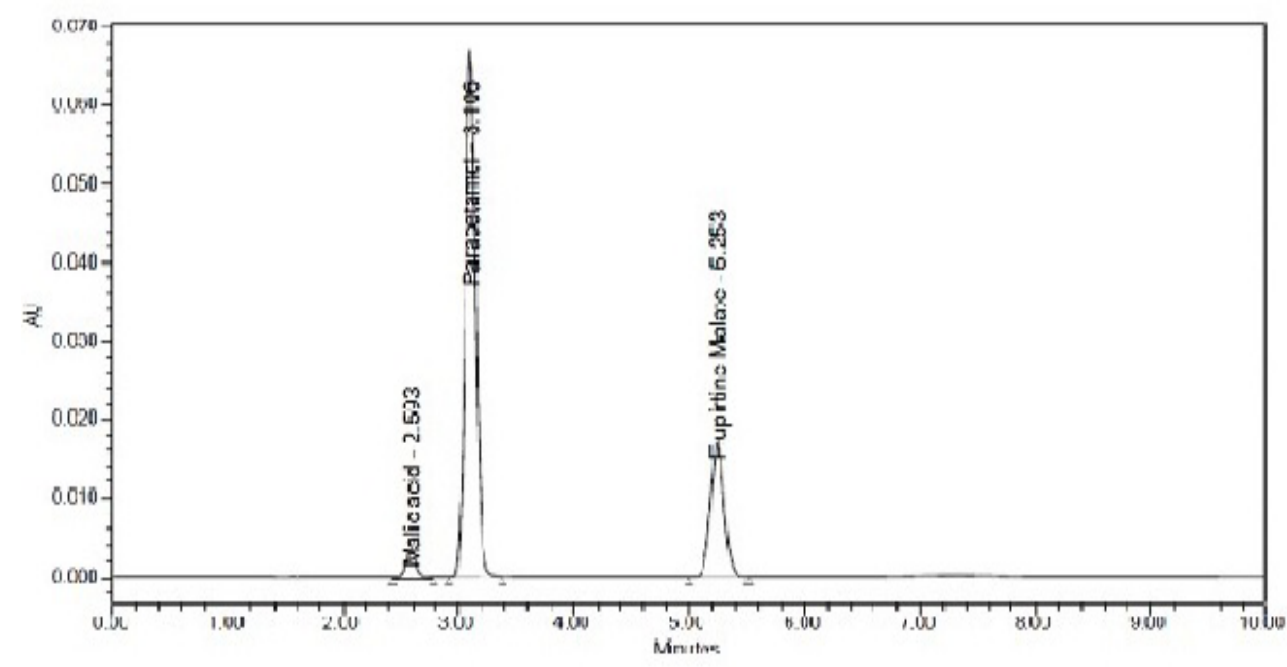

Figure 3: Accuracy at $50 \%$ level 


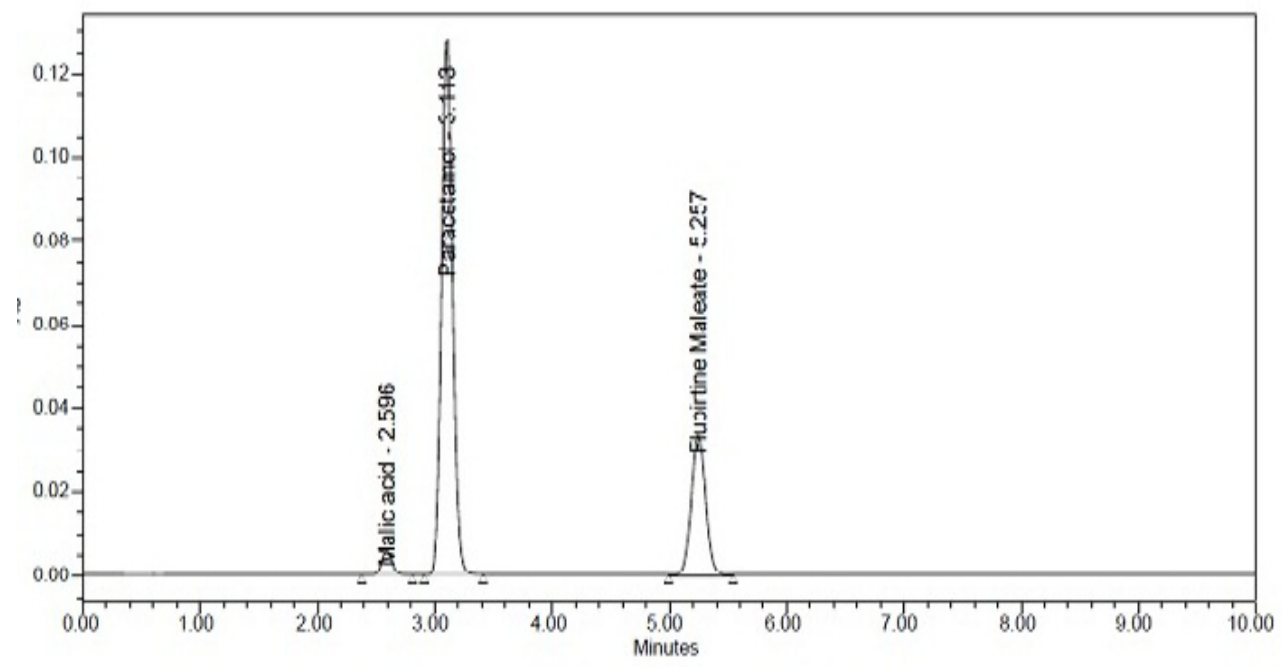

Figure 4: Accuracy at $100 \%$ level

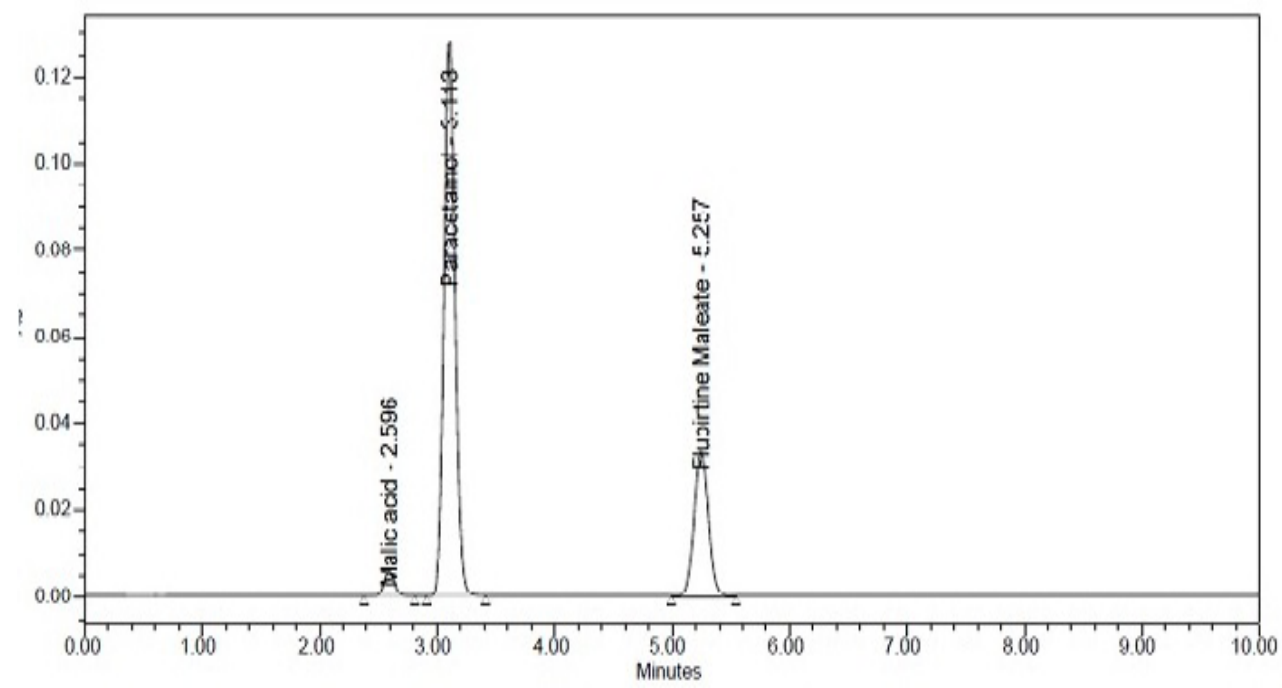

Figure 5: Accuracyat $150 \%$ level

\begin{tabular}{|c|c|c|c|c|}
\hline $\begin{array}{l}\text { Sample } \\
\text { Weight(mg) }\end{array}$ & Paracetamol & Flupritine & $\begin{array}{l}\text { \% Assay } \\
\text { (Paracetamol) }\end{array}$ & $\begin{array}{l}\text { \% Assay } \\
\text { (Flupritine) }\end{array}$ \\
\hline 68 & 844123 & 281326 & 99.5 & 99.9 \\
\hline 68 & 844905 & 282136 & 99.6 & 100.2 \\
\hline 68.1 & 845213 & 282675 & 99.5 & 100.2 \\
\hline 68.3 & 845540 & 283125 & 99.3 & 100.1 \\
\hline 68.8 & 845658 & 283340 & 98.6 & 99.4 \\
\hline \multirow[t]{3}{*}{68.6} & 844890 & 283905 & 98.8 & 99.9 \\
\hline & & Average Assay & 99.2 & 100.0 \\
\hline & & \%RSD & 0.42 & 0.30 \\
\hline
\end{tabular}




\begin{tabular}{|c|c|c|c|c|}
\hline Sample Weight & Paracetamol & Flupritine & $\begin{array}{c}\text { \%Assay } \\
\text { Paracetamol) }\end{array}$ & $\begin{array}{c}\text { \% Assay } \\
\text { (Flupritine) }\end{array}$ \\
\hline 68 & 854365 & 290143 & 100.7 & 103 \\
\hline 68 & 859904 & 288951 & 101.4 & 102.6 \\
\hline 68.9 & 866436 & 291254 & 100.8 & 102.1 \\
\hline 68.9 & 857650 & 289045 & 99.8 & 101.3 \\
\hline 68.9 & 869054 & 292109 & 101.1 & 102.4 \\
\hline 68.8 & 869434 & 293246 & 101.3 & 102.9 \\
\hline \multicolumn{3}{|c|}{ Average Assay } & 101.0 & 102.4 \\
\hline & & \%RSD & 0.3 & 0.61 \\
\hline
\end{tabular}

\section{Flupirtine Maleate}

Accurately weighed quantity $10 \mathrm{mg}$ of Flupirtine Maleate was transferred into $100 \mathrm{~mL}$ of volumetric flask, add 30 $\mathrm{ml}$ diluent and sonicated to dissolve and dilute to volume with diluent. (Stock solution). From the above solution 10 $\mathrm{ml}$ was taken into $100 \mathrm{ml}$ volumetric flask and diluted to volume with diluent.

\section{Preparation of sample solution}

Previously grinded powder equivalent to $68.094 \mathrm{mg}$ weight was transferred into $100 \mathrm{~mL}$ volumetric flask, added 30 $\mathrm{mL}$ of diluent, sonicated to dissolve for 10 minutes and diluted to volume with diluent. The solution was filtered through $0.45 \mu$ filter. $10 \mathrm{ml}$ of filtrate was diluted to 100 $\mathrm{ml}$ with diluent.

\section{Method validation}

\section{System suitability studies}

The concept behind the system suitability test is to ensure that the complete testing system is suitable for the intended application. The results of system suitability are presented in Table 1.

\section{Specificity}

Specificity is the ability of the developed method to detect the analyte in the presence of components which may be expected to be present. Typically these might include impurities, degradants, matrix, etc.

\section{Accuracy}

The accuracy of an analytical procedure expresses the closeness of the agreement between the actual values to the mean analytical value. The accuracy of the method was determined by recovery experiments. The recovery studies were carried out at three concentration levels. Each level was repeated for three times. The percentage recovery and standard deviation was calculated. The mean recoveries of Paracetamol, Flupirtine Maleate were found between $98 \%$ to $102 \%$. The results indicated good accuracy of the method for the determination of analyzed drugs as revealed by mean recovery data. The results are presented in Table $2 \& 3$. The accuracy at three levels was shown in Figures 3, 4, \& 5 .

\section{Precision}

The precision of an analytical procedure expresses the closeness of agreement (degree of scatter) between a series of measurements obtained from multiple sampling of the same homogeneous sample under the prescribed conditions. The precision of the method was demonstrated by intra-day and inter-day variation studies. In the intra-day studies the assay on six test preparations were performed by injected into the chromatographic system as per the test method. The $\%$ assay of drug and percentage RSD were calculated. The inter-day variations of the method also determined by using six replicate injections of the same concentration and analyzed on two consecutive days and response factor of drugs peaks and percentage RSD was calculated. From the data obtained, the developed RPHPLC method was found to be precise. The results are presented in Table $4 \& 5$.

\section{Linearity}

The linearity of an analytical procedure is its ability (within a given range) to obtain test results which are directly proportional to the concentration (amount) of analyte in the sample. Chromatographic method was tested for linearity by plotting peak area against concentration of solutions. The plot of peak area versus the respective concentrations of Paracetamol and Flupirtine Maleate were found to be linear in the concentration range of $8-50 \mu \mathrm{g} /$ $\mathrm{mL}$ and $2.5-15 \mu \mathrm{g} / \mathrm{mL}$ respectively. The regression equation for Paracetamol is $y=26287 x-4353$ with a coefficient of correlation $\left(\mathrm{R}^{2}\right)$ of 0.99 . The regression equation for 


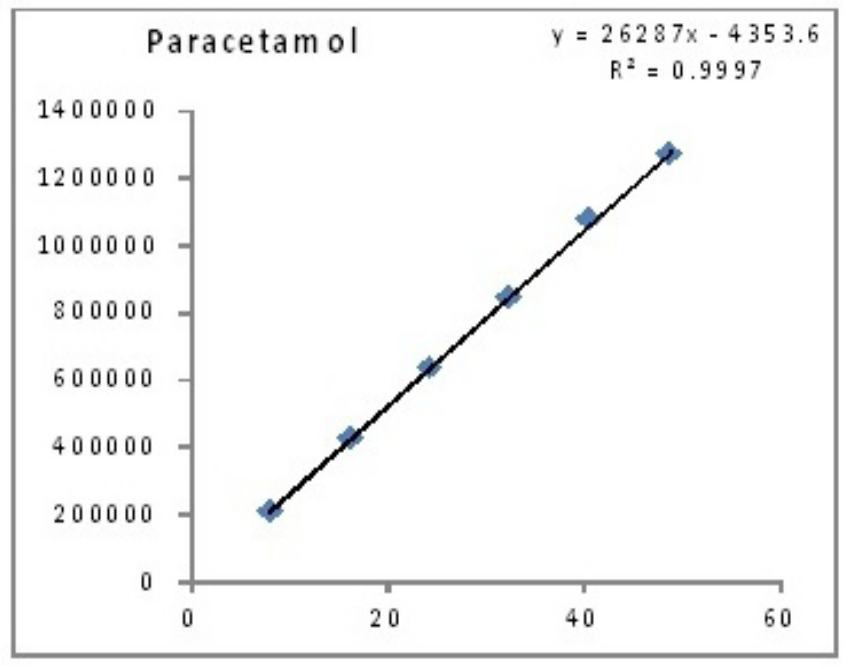

Figure 6: Linearity of Paracetamol

Flupirtine Maleate is $y=28235 x-906.3$ with a coefficient of correlation $\left(\mathrm{R}^{2}\right)$ of 1 . The results shows that an excellent correlation exists between areas and concentration of drugs within the concentration range indicated above. And the results for calibration curves are given in Figure $6 \& 7$. The results are presented in Table 6 .

\section{Limit of Detection and Limit of Quantification (LOD\&LOQ)}

The detection limit of an individual analytical procedure is the lowest amount of analyte in a sample which can be detected but not necessarily quantitated as an exact value. The quantitation limit of an individual analytical procedure is the lowest amount of analyte in a sample which can be quantitatively determined with suitable precision and accuracy. The quantitation limit is a parameter of quantitative assays for low levels of compounds in sample matrices, and is used particularly for the determination of impurities and/or degradation products.

(a) $\mathrm{LOD}=3 / \mathrm{s} / \mathrm{n} * 100 \%$ conc

(b) $\mathrm{LOQ}=10 / \mathrm{s} / \mathrm{n} * 100 \%$ conc

$\mathrm{LOD}=3 / 2415^{*} 2000=2.484($ Paracetamol $)$

$\mathrm{LOQ}=10 / 2415 * 2000=8.281($ Paracetamol $)$

$\mathrm{LOD}=3 / 128 * 10=0.2344$ (Flupirtine Maleate)

$\mathrm{LOQ}=10 / 128 * 10=0.7813$ (Flupirtine Maleate)

\section{Robustness}

The robustness of an analytical procedure is a measure of its capacity to remain unaffected by small, but

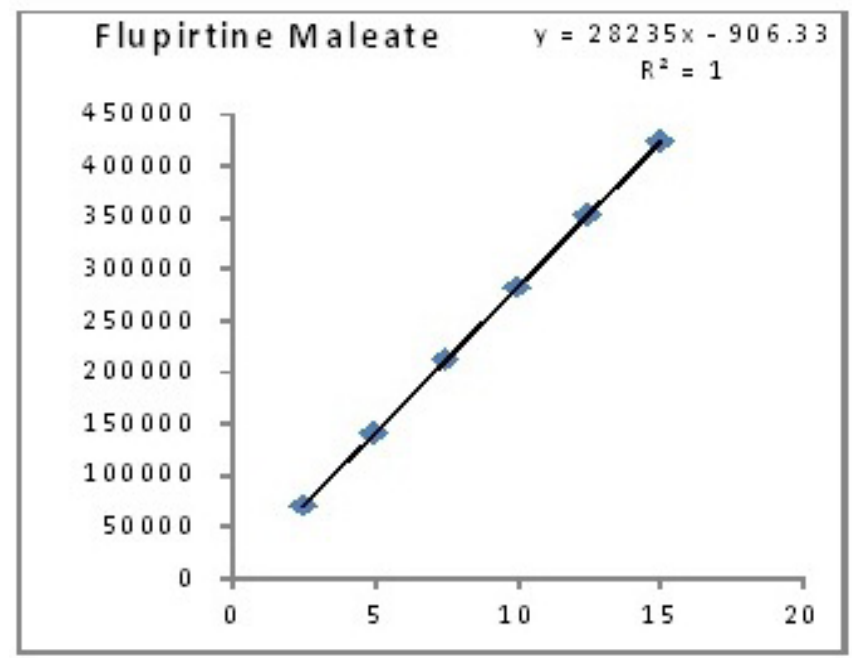

Figure 7: Linearity of Flupritine maleate

deliberate variations in method parameters and provides an indication of its reliability during normal usage. The Robustness of the method was determined by making slight changes in the chromatographic conditions i.e. flow variation $\pm 10 \%(0.9 \mathrm{ml}$ and $1.10 \mathrm{ml} / \mathrm{min})$, temp variation $\pm 5 \%$ variation $\left(25^{\circ} \mathrm{c}\right.$ and $\left.35^{\circ} \mathrm{c}\right)$. It was observed that there were no marked changes in the system suitability results, which demonstrated that the RP-HPLC method developed was robust.

\section{Forced Degradation Studies}

The stability studies were determined by applying the physical stress (acid, base, thermal and light) to the product. It was observed that there were marked degradation in the chromatograms, and the data given in Tables $7 \& 8$.

\section{RESULTS AND DISCUSSION}

System suitability parameters are retention time, resolution, tailing and plate count were shown uniformity and \%RSD was less than 1 (limit of $\%$ RSD is less than $2.0 \%$ ) so we can say that system is suitable for the analysis. Method specificity was concluded by standard chromatogram and formulation chromatogram. There was no interference from placebo and excipients peaks with standard and analytic peaks. These results demonstrate the absence of interference from other materials. Hence it confirms the specificity of the proposed method. The method accuracy was evaluated by recovery studies. Paracetamol and Flupirtine Maleate recovery was found between 98\%$102 \%$ and also percentage RSD was very low so method 


\begin{tabular}{llll}
$\begin{array}{l}\text { Table 6: Linearity of Paracetamol and Flupritine maleate } \\
\text { Paracetamol }\end{array}$ & \multicolumn{3}{c}{ Flupritine } \\
Conc $(\mu \mathrm{g})$ & Area & Conc $(\mu \mathrm{g})$ & Area \\
8.125 & 209068 & 2.5 & 69326 \\
16.25 & 423491 & 5 & 140749 \\
24.375 & 635779 & 7.5 & 211283 \\
32.5 & 844012 & 10 & 280920 \\
40.625 & 1075477 & 12.5 & 351635 \\
48.75 & 1271319 & 15 & 422976
\end{tabular}

\begin{tabular}{|c|c|c|c|c|c|c|}
\hline $\begin{array}{l}\text { Mode of } \\
\text { degradation }\end{array}$ & Conditions & Area & $\%$ Assay & \% Deg. & Purityangle & $\begin{array}{l}\text { Purity } \\
\text { Threshold }\end{array}$ \\
\hline Control & Notreatment & - & - & - & - & - \\
\hline $\begin{array}{l}\text { Acid } \\
\text { degradation(5 N } \\
\mathrm{HCl})\end{array}$ & $40^{\circ} \mathrm{C} / 5 \mathrm{~min}$ & 257127 & 81 & -19 & 0.433 & 1.023 \\
\hline $\begin{array}{l}\text { Alkali degradation } \\
(1 \mathrm{~N} \mathrm{NaOH})\end{array}$ & $80^{\circ} \mathrm{C} / 1 \mathrm{hr}$ & 240724 & 80 & -20 & 0.387 & 0.895 \\
\hline $\begin{array}{l}\text { Light (200 watts } \\
\text { hrs/min) }\end{array}$ & $105^{\circ} \mathrm{C} / 72 \mathrm{hrs}$ & 214259 & 90 & -10 & 0.285 & 0.566 \\
\hline Heat $\left(105^{\circ} \mathrm{C} / 72 \mathrm{hr}\right.$ & $25^{\circ} \mathrm{C} / 72 \mathrm{hrs}$ & 274441 & 93 & -7 & 0.354 & 0.565 \\
\hline
\end{tabular}

\begin{tabular}{|c|c|c|c|c|c|c|}
\hline Mode of degradation & Conditions & Area & $\%$ Assay & \% Deg. & Purity angle & Purity Threshold \\
\hline $\begin{array}{l}\text { Acid degradation }(5 \mathrm{~N} \\
\mathrm{HCl})\end{array}$ & $40^{\circ} \mathrm{C} / 5 \mathrm{~min}$. & 823568 & 80 & -20 & 0.324 & 0.675 \\
\hline $\begin{array}{l}\text { Alkali degradation (1N } \\
\mathrm{NaOH})\end{array}$ & $80^{\circ} \mathrm{C} / 1 \mathrm{hr}$ & 817961 & 84 & -16 & 0.332 & 0.702 \\
\hline $\begin{array}{l}\text { Light ( } 200 \text { watts hrs/ } \\
\text { min) }\end{array}$ & 821226 & 92 & -8 & 0.276 & 0.465 & \\
\hline Heat $\left(105^{\circ} \mathrm{C} / 72 \mathrm{hr}\right)$ & $25^{\circ} \mathrm{C} / 72 \mathrm{hr}$. & 820010 & 92 & -8 & 0.314 & 0.657 \\
\hline
\end{tabular}

is accurate. Calibration curve was plotted concentration versus areas. Linear correlation was found to be y $=26287 \mathrm{x}-4353$ for Paracetamol, $\mathrm{y}=28235 \mathrm{x}-906.3$ for Flupirtine Maleate. The intra-day and inter-day variations were calculated in terms of $\%$ RSD. The low $\%$ RSD results revealed that method was precise. Method robustness was performed by making small deliberal changes in the chromatographic conditions. The robustness results proved that the method was robust. Degradation studied were performed under different conditions and in each condition it was observed that the purity threshold value was found to be greater than the purity angle value which indicates that the peak is pure i.e. no interference of degradants with the analyte peak.

\section{CONCLUSION}

The proposed HPLC method was found to be simple, precise, accurate and sensitive for the simultaneous estimation of Paracetamol, Flupirtine Maleate in pharmaceutical dosage forms. Degradation studies reveals that the developed method was stability indicating Hence, this method can easily and conveniently adopt for routine quality control analysis of Paracetamol, Flupirtine Maleate in pure and its pharmaceutical dosage forms.

\section{CONFLICT OF INTEREST}

This study was unfunded. There were no conflicts of interest.

\section{ACKNOWLEDGEMENT}

We acknowledge the pharmacy departments of Jawaharlal Nehru technological university, Kakinada and Andhra university for their assistance. 


\section{REFERNCES}

1. Karen methling et al. investigation of the in vitro metabolism of Analgesic flupiritine. The American society for Pharmacology and experimental Therapeutics; 2008. 1-49.

2. Available from URL http://www.drug2day.com/ index.php/drug/ display/27971 (accessed on Sep 12, 2011

3. Sweetman SC, Martindale. The complete drug reference, $34^{\text {th }}$ ed., Royal Pharmaceutical Society of Great Britain, London; 2005.

4. Aneesh TP, Amal D. Method development and validation for estimation of flupirtine maleate in bulk and pharmaceutical dosage forms using U.V-Visible Spectrophotometry. IRJP. 2011 2(12): 179-182.

5. Khanage SG, Mohite PB, Jadhav S. Development and validation of UV-Visible spectrophotometric method for simultaneous determination of eperisone and paracetamol in solid dosage form. Adv Pharm Bull. 2013; 3(2): 447-51.

6. Kumar AM, Swathi A, Supriya D, Prasad VVLN, Prakash V, Diwan. Development and validation of UV spectrophotometric method for simultaneous estimation of ibuprofen, paracetamol and caffeine in pharmaceutical dosage Form. Am J Pharm Tech Res. 2012; 2(6): 483.

7. Kapil K, Naik S, Garima J, Mishra N. Spectrophotometric method for simultaneous estimation of paracetamol and domperidone in Tablet formulation. Asian J Res Chem. 2009; 2(2): 112-4.

8. Shah U, Kavad M, Raval M. Development and validation of UV spectrophotometric method for estimation of paracetamol and flupirtine maleate in bulk and pharmaceutical dosage form. Int $\mathrm{J}$ Pharm Tech Res. 2013; 5(3): 1007-13.

9. Attimarad M. Simultaneous determination of paracetamol and lornoxicam by RP-HPLC in bulk and Tablet formulation. Pharm Ana J In pharm Asoc. 2011; 2(1): 61-6.

10. Gopinath R, Rajan S, Meyyanathan SN, Krishnaveni N, Suresh B. A RP-HPLC method for simultaneous estimation of paracetamol and aceclofenac in Tablets. Indian J Pharm Sci. 2007; 69(1): 137-40.

11. Gowramma B, Rajan S, Muralidharan S, Meyyanathan SN, Suresh B. A Validated RP-HPLC method for simultaneous estimation of paracetamol and diclofenac potassium in pharmaceutical formulation. Int J Chem. Tech. 2010; 2(1): 676-80.

12. Rao BM, Patel B, Jivani N, Digbijay K, Nitin S. Development and validation of HPLC method for simultaneous estimation of paracetamol and tapentadol hydrochloride in their combined dosage form. Inventi: ppaqa/1025/13, 2013.

13. Patel A, Patel N, Patel M, Lodha A, Chaudhuri J, Jadia $P$, et al. Development and validation of analytical methods for the simultaneous estimation of lornoxicam and paracetamol from their pharmaceutical dosage form. IOSR J Pharm. 2012; 2(3): 364-65.

14. Xing L, LIU, Ya XIAD, Tao GUO. Determination of the concentration of flupirtine in human plasma by RP-HPLC. J Shenyang Pharm U. 2010; 27(7): $559-62$.

15. ICH, Q2 (R1) validation of analytical procedure, text and methodology. International conference on Harmonization, Nov; 1996.

16. International Conference on Harmonization (ICH) of technical requirements for registration of pharmaceuticals for human use: Validation of analytical procedures. Text and methodology Q2 (R1); 2005. 